\title{
An Experimental Investigation of Dynamic Properties of Fiber-Reinforced Tire-Derived Lightweight-Aggregate Concrete
}

\author{
Fariborz M. Tehrani, Nazmieh A. Masswadi, Nathan M. Miller, and Arezoo Sadrinezhad
}

\begin{abstract}
This paper presents the results of an experimental study to investigate dynamic properties of polypropylene fiberreinforced concrete beams with lightweight expanded shale (ES) and tire-derived aggregates (TDA). The mixture design followed past experiences in combining ES and TDA to enhance toughness and energy absorption in flexural behavior. The new mixture also contained $2 \%$ fiber by volume to improve such properties further. Experiments included compressive testing on cylindrical specimens as well as flexural testing on rectangular specimens to verify mechanical properties of fiber-reinforced tire-derived lightweight aggregate concrete (FRTDLWAC) subject to static loading. The results of these experiments confirmed reduction of mechanical strength due to addition of TDA and improvements in flexural strength due to fiber reinforcement. The dynamic testing included non-destructive impact loads applied to flexural specimens using a standard Schmidt hammer. A highspeed camera recorded the response of the system at 200 frames per second to allow detailed observations and measurements. Interpretation of energy-based dynamic results revealed that TDA enhances energy absorption through damping in flexural behavior. Results also indicated that fiber reinforcement reduces the amount of absorbed dynamic energy, even though; it enhances the absorbed strain energy due to crack bridging effect.
\end{abstract}

Index Terms-Damping, Dynamic Tests, Fiber Reinforced Concrete, Mechanical Properties.

\section{INTRODUCTION}

The energy absorption and damping characteristics of structural materials are essential elements in determining the performance-based capacity of structures subjected to dynamic loads [1-3]. Previous studies have shown that some materials such as rubber can be utilized as alternative aggregates to enhance the ductility, inhibit cracking, and thus mitigate brittleness of concrete [4-5]. However, it has been shown that adding rubber aggregates to a concrete matrix decreases the physical and mechanical properties of the hardened concrete such as density, compressive strength, and modulus of elasticity [6]. Existing literature shows that substitution of aggregates with rubber particles results in a similar trend. Typical conclusions of such observations

Published on June 15, 2020

F. M. Tehrani, California State University, Fresno, USA

(e-mail: ftehrani @ csufresno.edu)

Nazmieh A. Masswadi, California State University, Fresno, USA.

(e-mail: nazmiehm ${ }^{\circledR}$ mail.fresnostate.edu)

N. M. Miller, California State University, Fresno, USA.

(e-mail: natemiller@mail.fresnostate.edu)

A. Sadrinezhad, California State University, Fresno, USA.

(e-mail: asadrinezhad@mail.fresnostate.edu) includes suggestive limits of rubber content for structural and non-structural concrete, say $25 \%$ and $40 \%$ of total aggregate volume respectively [7-9]. Miller and Tehrani (2017) showed that the replacement of lightweight coarse aggregates with rubber aggregates by 20, 40, 60, 80 and $100 \%$ also causes a decrease in mechanical properties as rubber content increased. However, toughness was shown to increase with the addition of rubber content sometimes as much as twice when comparing maximum-rubber-content to zero-rubber-content mixes [10].

The weakening of the concrete's mechanical properties can be attributed to the rubber's weak mechanical properties as crumb rubber introduces weak regions into the matrix of the concrete. Though these weaknesses exist, rubber has a bonding strength within the concrete that inhibits cracking and increases the toughness [11]. Internally, the microstructure of the concrete changes with the addition of rubber aggregates as the different interfaces between the cement paste and brittle aggregates are replaced with ductile rubber shreds embedded into the cementitious matrix [1213]. Thus, while the mechanical properties of rubberized concrete have been shown to decrease with the increase of rubber aggregates, the same specimens tend to have reduced damages from impact loading. In the rubberized concrete, rubber aggregates absorb the energy and increase the energy absorption of the specimen. This can account for the diminished damage upon impact. Topcu and Avcular (1997) performed weight-drop impact test and reported reduced damages resulting from collision for the rubberized specimens [14]. Moreover, the addition of rubber aggregates has been shown to increase damping ratios of rubberized concrete specimens by up to $100 \%$ compared to conventional specimens. Xue and Shinozuka (2013) reported that rubberized concrete columns containing 5 to $20 \%$ rubber replacement of coarse aggregate had up to $62 \%$ increases of damping ratio compared to normal concrete, when subjected to vibration induced by a hammer. This increase in damping ratio confirms the idea that rubber within the concrete dissipates the energy better than mineral aggregates in conventional concrete [15]. Zheng et al. (2008) reported rubberized concrete beams subjected to small-amplitude free vibrations, where their movements were recorded with accelerometers. Again, the damping ratios increased with the increase of rubber content, which suggests that more rubber in the concrete mix results in dissipation of more energy [16].

Literature also shows that fiber-reinforcement is another effective method in increasing the ductility and toughness, and reducing crack propagation of brittle materials such as 
concrete [17-20]. This behavior extends to lightweight aggregate concrete such as expanded shale [21-23]. This research presents the results of an experimental study that investigates dynamic properties of polypropylene fiberreinforced concrete beams with lightweight expanded shale aggregates (LWA) and tire-derived aggregates (TDA). Experimental results include compressive and flexural strengths as well as toughness and ductility ratio. Conclusions assess the effect of fiber reinforcement on dynamic properties of the LWA/TDA concrete.

\section{Methods And Materials}

\section{A. Specimens}

Specimens include standard cylinders (0.15-m-diameter by 0.30 -m-height) for compressive and splitting-tensile tests, and two sizes of beams $(0.15 \times 0.15 \times 0.50 \mathrm{~m}$ and $0.10 \times 0.10 \times 1.0 \mathrm{~m})$ for flexural and damping tests. Table I displays the number of specimens used per test.

TABLE I: NUMBER OF LAB SPECIMENS

\begin{tabular}{llll}
\hline \hline \multirow{2}{*}{ Type } & $\begin{array}{l}\text { Mix-1 } \\
\text { LWAC }^{1}\end{array}$ & $\begin{array}{l}\text { Mix-2 } \\
\text { TDLWAC }^{2}\end{array}$ & $\begin{array}{l}\text { Mix-3 } \\
\text { FRTDLWAC }^{3}\end{array}$ \\
\hline Cylinder $0.15 \times 0.30 \mathrm{~m}$ & 4 & 3 & 4 \\
\hline Beam $0.1 \times 0.1 \times 1.0 \mathrm{~m}$ & 4 & 3 & 5 \\
\hline $\begin{array}{l}\text { Beam } 0.15 \times 0.15 \times 0.5 \\
\mathrm{~m}\end{array}$ & 2 & 2 & 2 \\
\hline
\end{tabular}

${ }^{1}$ Light-Weight Aggregate Concrete

2 Tire-Derived Light-Weight Aggregate Concrete

${ }^{3}$ Fiber-Reinforced Tire-Derived Light-Weight Aggregate Concrete

\section{B. Mixture Proportions}

Three different mixes with a target compressive strength of $21 \mathrm{MPa}$ for the control mix were adopted from the work done by Miller and Tehrani (2017) [10]. The control mix, mix-1, consisted of Type-1 cement, all-purpose sand, and lightweight expanded shale aggregates, labeled as Lightweight Aggregate Concrete (LWAC) as shown in figure 1 [23]. The second set of specimens had the same constituents as mix- 1 , but $80 \%$ of expanded shale aggregates were replaced by tire-derived aggregates (TDA) with uniform gradation, labeled as Tire-Derived Lightweight Aggregate Concrete (TDLWAC). The third mix was identical to the mix-2, but contained a $2 \%$-by-volume addition of 19-mm-long polypropylene fibers, labeled as Fiber-Reinforced Tire-Derived Lightweight Aggregate Concrete (FRTDLWAC). Table II shows the weight of each constituent used per mix.

TABLE II: MIXTURE PROPORTIONS

\begin{tabular}{llll}
\hline \hline Constituents & $\begin{array}{l}\text { Mix-1 } \\
\text { LWAC }\end{array}$ & $\begin{array}{l}\text { Mix-2 } \\
\text { TDLWAC }\end{array}$ & $\begin{array}{l}\text { Mix-3 } \\
\text { FRTDLWAC }\end{array}$ \\
\hline Cement $(\mathrm{kg})$ & 54 & 53 & 53 \\
\hline Water $(\mathrm{l})$ & 32 & 26 & 26 \\
\hline $\begin{array}{l}\text { Normalweight fine } \\
\text { aggregate }(\mathrm{kg})\end{array}$ & 82 & 80 & 80 \\
\hline $\begin{array}{l}\text { Lightweight coarse } \\
\text { aggregate }(\mathrm{kg})\end{array}$ & 48 & 9.4 & 9.4 \\
\hline $\begin{array}{l}\text { Tire-derived } \\
\text { aggregate }(\mathrm{kg})\end{array}$ & 0 & 27 & 27 \\
\hline $\begin{array}{l}\text { Polypropylene fiber } \\
(\mathrm{kg})\end{array}$ & 0 & 0 & 1.7 \\
\hline \hline
\end{tabular}

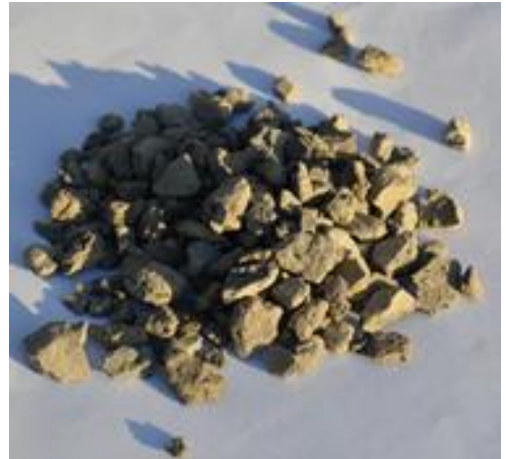

Fig. 1. Lightweight coarse expanded shale aggregate.

\section{Placement and Curing}

Molds were prepared prior to mixing the concrete constituents. Mold types included plastic cylinders, heavy plastic molds for $0.15 \times 0.15 \times 0.50 \mathrm{~m}$ beams, and steel and wood molds for $0.10 \times 0.10 \times 1.0 \mathrm{~m}$ beams. Specimens were kept covered in moist towels for up to a week, and then, removed from molds and placed in a curing room to cure for the remainder of their 28-day curing standard.

\section{Compression Testing}

Compression testing was performed using a Tinius Olson Universal Testing Machine with a 500-kN load cell in compliance with ASTM C39 for compression testing of cylindrical specimens [24]. The PL-60 strain gauges were chosen as specified by the manufacturer [25]. Strain gauges were positioned on the transverse center of the cylinders (Fig. 2). There was one gauge on each quarter of the cylinder face (Fig. 3). Longitudinal deformation of the cylinders was measured directly by the universal testing machine. The information gathered from these tests was used to generate stress-strain curves and calculate compressive toughness.
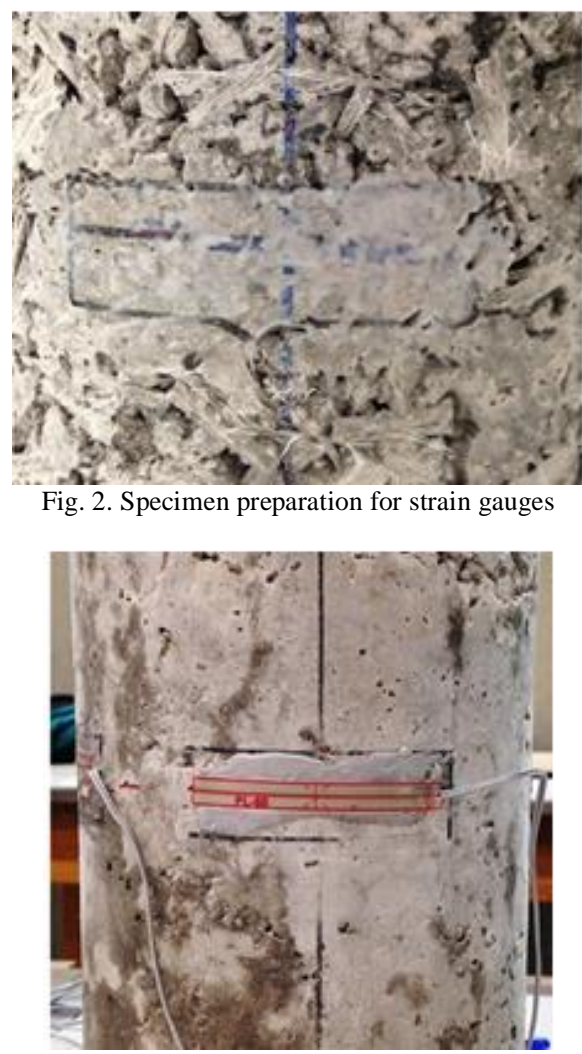

Fig. 3. Strain gauge placement. 


\section{E. Flexural Testing}

The static flexure testing was performed per ASTM C78 [26]. The $0.15 \times 0.15 \times 0.50 \mathrm{~m}$ beams were used with a $0.45-\mathrm{m}$ clear span. The clear span was divided by three to have a $0.15-\mathrm{m}$ distance between the rollers that induced the loading of the machine on the top of the beam. Strain gauges were attached to the side faces of the beam parallel to the clear span at $38 \mathrm{~mm}$ depths from the major extreme fibers.

\section{F. Impact Testing}

Principles of potential and kinetic energy were applied to create a Newton's Cradle set up that measures the energy loss from each concrete mix as shown in figure 4. A control sheet of steel was impact loaded on one face in order to move a mass hanging from a string at the opposite face of the steel sheet. This provided a reference for the amount of energy that was put into the system. The impact on the steel plate and the subsequent motion of the hanging mass were captured by means of a high speed camera at 2000 frames per second. The camera was set as close as possible to the profile view of the impacted specimens so that its view would be perpendicular to the plane of impact. Frames produced by this camera allowed to measure the distance travelled over time to calculate a velocity. This velocity was used for the energy equation, $E=0.5 m v^{2}$ where $\mathrm{E}$ is energy, $\mathrm{m}$ is the mass and $\mathrm{v}$ is the velocity. The same procedure was performed for all $0.10 \times 0.10 \times 1.0 \mathrm{~m}$ beams created in all three mixes. Beam supports were placed 0.91 $\mathrm{m}$ apart and fixed to a strong-floor to ensure a static set up. The beams were left with 50-mm over-hanging on either side with a clamp at each end fixing the beam to the beam supports. This ensured that any movement or reverberation from the impact load would not move the beam ends from its supports. The steel plate was clamped to the midsection of the concrete beam to not only protect the beam from being dented or damaged by the Schmidt hammer, but also to provide a basis of energy lost in the control system described above. The impact load from the hammer was applied to the same point on the steel plate behind the center of the beam, and the movement of the hanging mass was recorded by a high-speed camera at 400 frames per second. The mass' swing before it began to swing back was paused on video and measured for its height change from its original position. This height change along with its weight could be applied to the energy equation, $E=m g h$ where $g$ is the acceleration of gravity, and $h$ is the height, measured from the observed rise of the mass. If a mass with a certain potential energy swings to impact a material, the system loses some energy via the material that was impacted. It was assumed that the lost energy was damped by the material. The beginning and end position of the mass before and after impact were recorded by noting the $\mathrm{x}$ and $\mathrm{y}$ coordinates shown on the video viewer. Though these coordinates were in pixels, a ruler was placed on screen in order to determine a "conversion" of those pixels into millimeter units. This was done three times for each beam to have a collection of energy calculations per mix. Averaging or viewing a pattern for each mix allows for a comparison of energy losses to the steel plate set up. Impact load was applied via a Schmidt hammer, also referred to as "rebound hammers". The hammer works by means of a plunger that is pushed into a hollow tube containing a spring. The spring becomes contracted and sets the plunger in motion to shoot forward and impact the surface it is set upon [27]. Because the plunger had the potential for not hitting the same point accurately for each test, a simple hand level was attached to the hammer for reference (Fig. 4).

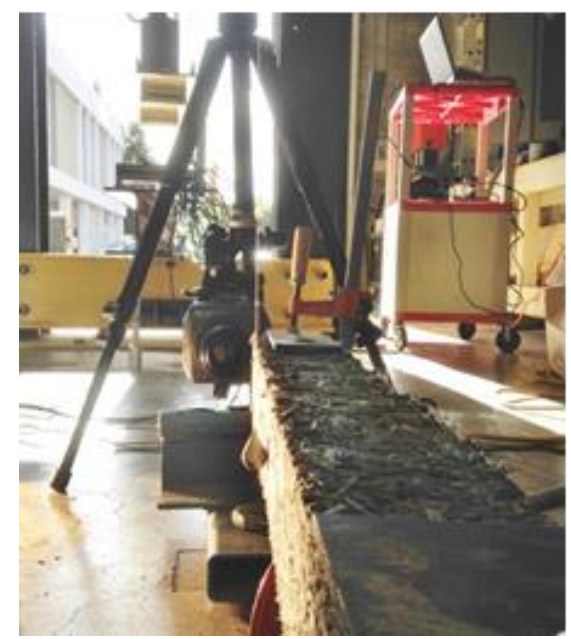

Fig. 4. Camera and hanging mass set-up.

\section{RESUlts}

\section{A. Compression Testing}

Figure 5 shows the results of the testing for all the cylinders from all three mixes. Compression results showed similarities to a previous study by Miller and Tehrani (2017) [10]. Table III indicates that TDA reduces the strength of the specimen, and thus, the overall energy absorbed by the specimen. But, application of fibers has increased the ductility and toughness by increasing the ultimate deformation of specimens.

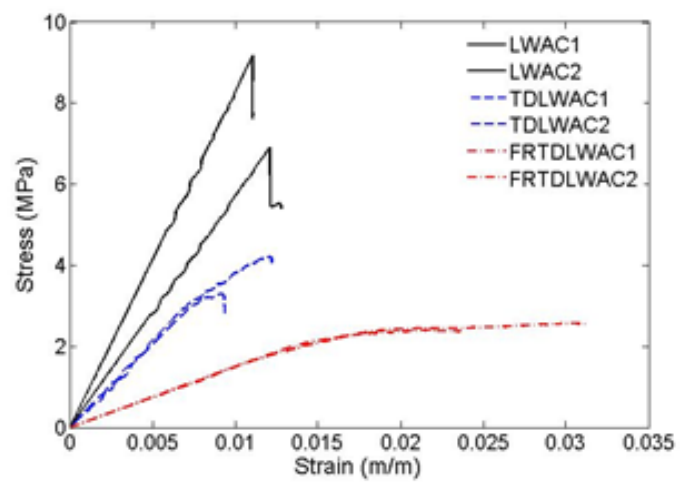

Fig. 5. Cylinder stress-strain results

TABLE III: COMPRESSION TESTING RESULTS

\begin{tabular}{lllll}
\multicolumn{5}{c}{ TABLE III: COMPRESSION TESTING RESULTS } \\
\hline \hline Constituents & Specimen & $\begin{array}{l}\text { Mix-1 } \\
\text { LWAC }\end{array}$ & $\begin{array}{l}\text { Mix-2 } \\
\text { TDLWAC }\end{array}$ & $\begin{array}{l}\text { Mix-3 } \\
\text { FRTDLWAC }\end{array}$ \\
\hline $\begin{array}{l}\text { Peak Stress } \\
(\mathrm{MPa})\end{array}$ & 1 & 9.18 & 3.29 & 2.56 \\
\hline $\begin{array}{lllll}\text { Strain at Peak } \\
\text { Stress }(\mathrm{m} / \mathrm{m})\end{array}$ & 1 & 6.92 & 4.22 & 2.39 \\
\cline { 2 - 5 } & 2 & 0.011 & 0.0092 & 0.031 \\
\hline $\begin{array}{l}\text { Total Energy } \\
(\mathrm{kPa}-\mathrm{m} / \mathrm{m})\end{array}$ & 1 & 0.012 & 0.012 & 0.021 \\
\cline { 2 - 5 } & 2 & 50.2 & 17.2 & 55.8 \\
\hline \hline
\end{tabular}

Specimens were also the same as the previous study by Miller and Tehrani (2017) [10]. Control specimens had long vertical cracks that went from the bottom surface to the top 
surface. As shown in figure 6, not only the cracks propagated through the entire axial length, but also the concrete outside of the cracks completely and cleanly separated from the core of the cylinder in slab-shape pieces. This happened to one or more sides of the cylinders and could be considered as Type 3 fracture pattern per ASTM C39 [24].

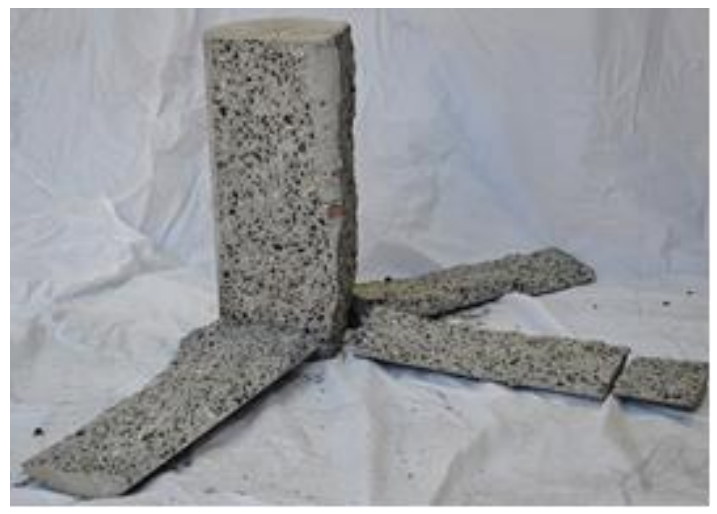

Fig. 6. Fracture failure of control cylinder.

Nearly all the cylinders containing mix-2 showed Type 4 fracture with a diagonal crack through one or two corners of one end of the cylinders (Fig. 7). Unlike the control specimens, the concrete outside of the crack did not separate from the main cylinder, but rather, stayed together. To view the internal faces of the fractures, one had to forcibly pull off and remove the damaged portion from the rest of the intact cylinder (Fig. 8).

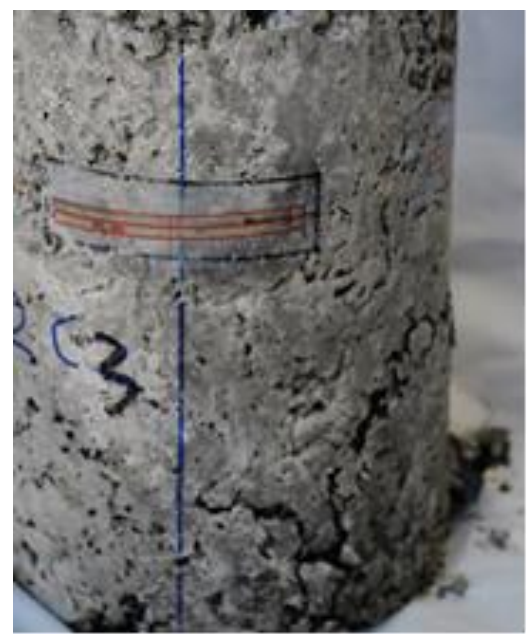

Fig. 7. Fracture failure of mix-2 cylinder

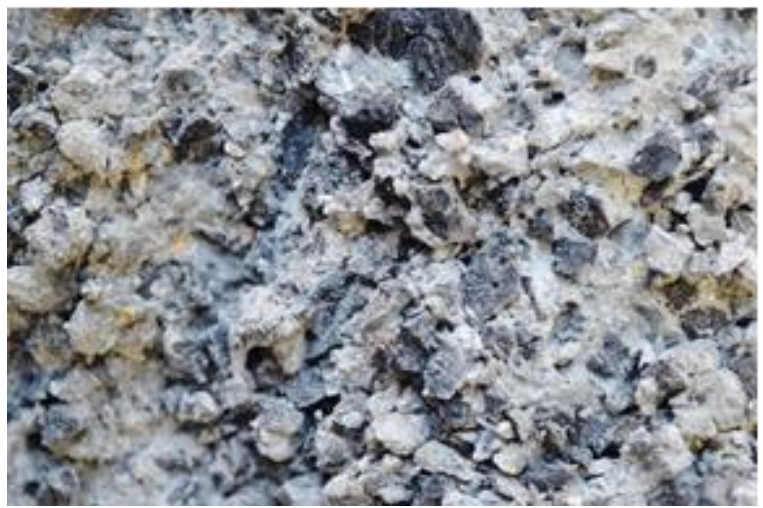

Fig. 8. Internal surface of failed mix-2 cylinder.

Cylinders containing fibers (mix-3) shared the same fracture characteristics as mix-2. More precisely, half of the cylinders showed a Type 4 fracture like those cylinders of mix-2, but the other half showed fracture Type 5 (Fig. 9). The fractured portions would not separate from the rest of the intact cylinder, but required even more force to separate than those cylinders of mix-2. It required the use of hand tools to separate the pieces (Fig. 10).

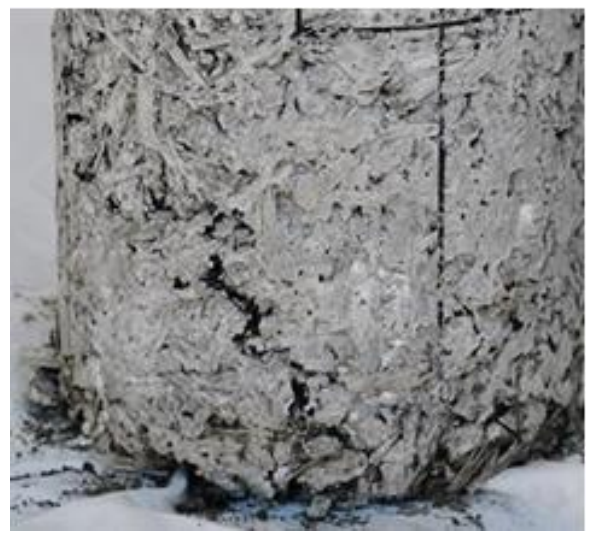

Fig. 9. Fracture failure of mix-3 cylinder

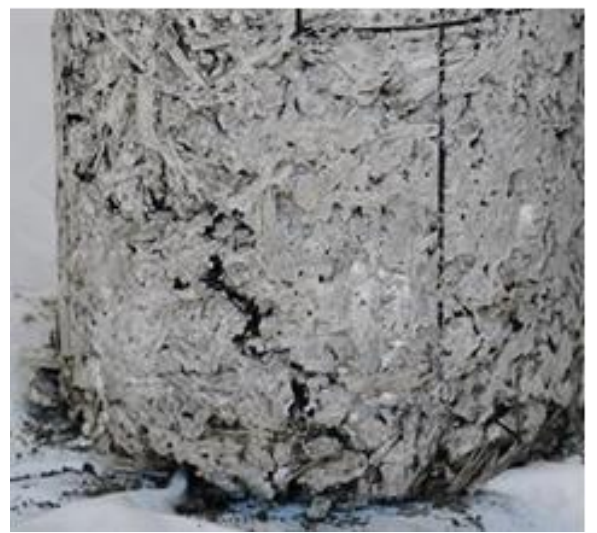

Fig. 10. Internal surface of failed mix -3 cylinder

\section{B. Flexural Testing}

Results of the flexure testing showed that the control specimens withstanding the highest applied load before fracture. It may be discerned from figure 11 that mix-3 specimens had higher flexural strength than those from mix2. Table 4 shows the results of the flexure tests. This table represents the flexural strength by means of a modulus of rupture calculation per ASTM C78 [26]. Similar to the results of compression testing, TDA reduced the strength of the concrete. However, fiber-reinforcement restored portion of the lost strength and substantially increased the ductility and toughness as shown in Figure 11.

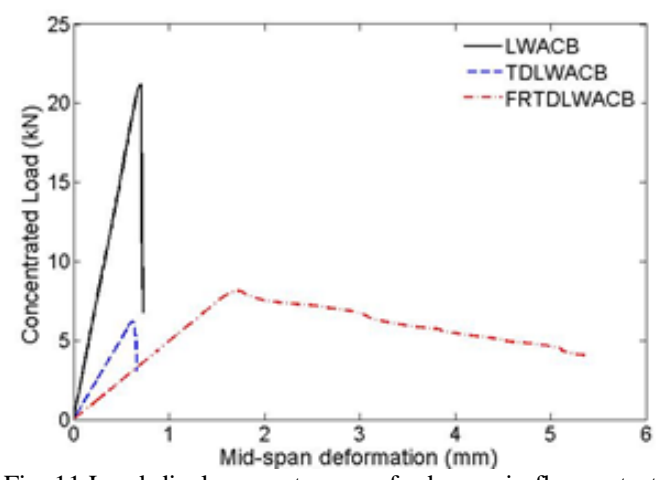

Fig. 11 Load-displacement curves for beams in flexure tests. 
TABLE IV: FLEXURAL TESTING RESULTS

\begin{tabular}{llll}
\hline \hline Mixture & $\begin{array}{l}\text { Mix-1 } \\
\text { LWAC }\end{array}$ & $\begin{array}{l}\text { Mix-2 } \\
\text { TDLWAC }\end{array}$ & $\begin{array}{l}\text { Mix-3 } \\
\text { FRTDLWAC }\end{array}$ \\
\hline Peak Load (kN) & 21.2 & 6.21 & 8.14 \\
\hline $\begin{array}{l}\text { Displacement at Peak } \\
\text { Load (mm) }\end{array}$ & 0.71 & 0.62 & 1.7 \\
\hline $\begin{array}{l}\text { Modulus of Rupture } \\
(\mathrm{MPa})\end{array}$ & 2.74 & 0.802 & 1.05 \\
\hline $\begin{array}{l}\text { Elastic Energy (kN- } \\
\text { mm) }\end{array}$ & 7.72 & 1.96 & 7.37 \\
\hline $\begin{array}{l}\text { Post-peak Energy } \\
(\mathrm{kN}-\mathrm{mm})\end{array}$ & 0.21 & 0.23 & 21.8 \\
\hline \hline
\end{tabular}

Figure 12 shows an image of the broken beam with mix-1 (LWAC) and confirms the observed brittle behavior in force-deformation curves. The failure of TDLWAC beam with mix-2 was similar to the control beam resulting in a surface shown in the figure 13. In contrast, Figure 14 shows the failed surface of the specimen with Mix-3 (FRTDLWAC), which contains numerous fibers pulled-out or failed during the flexure testing. Figure 15 is a close-up image that shows fibers bridging the tensile crack, with fibers pulled-out at the crack opening and other fibers still resisting near the tip of the crack.

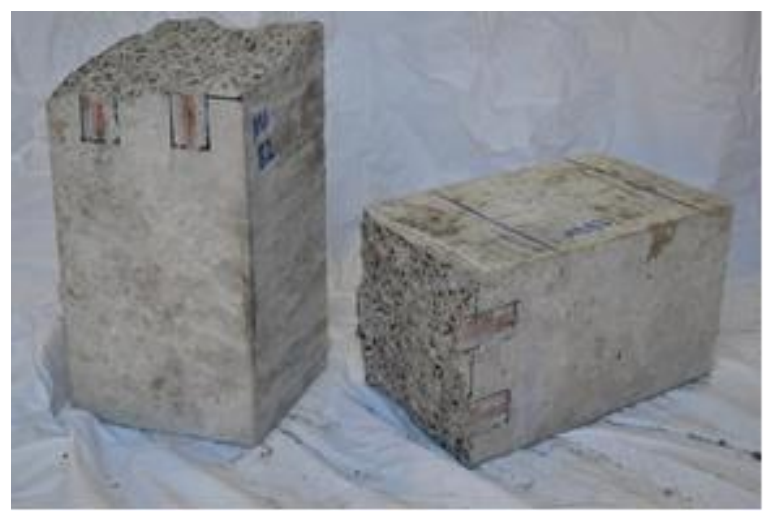

Fig. 12. Fractured mix-1 beam after flexural testing

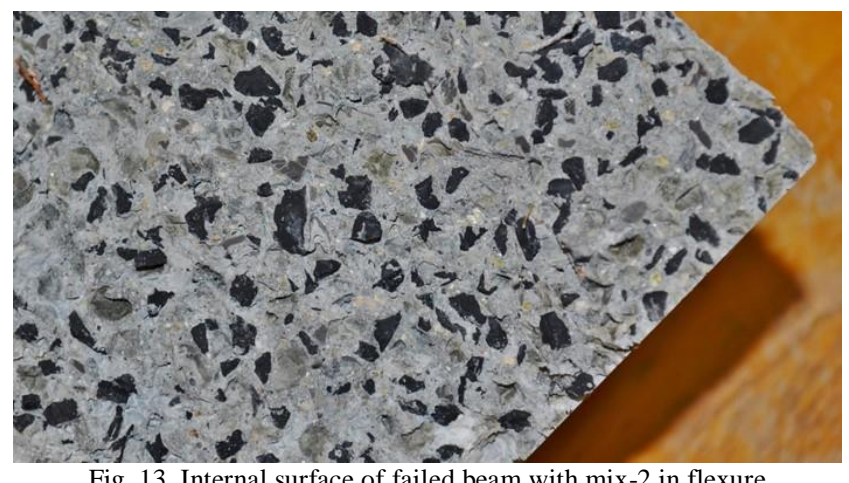

Fig. 13. Internal surface of failed beam with mix-2 in flexure

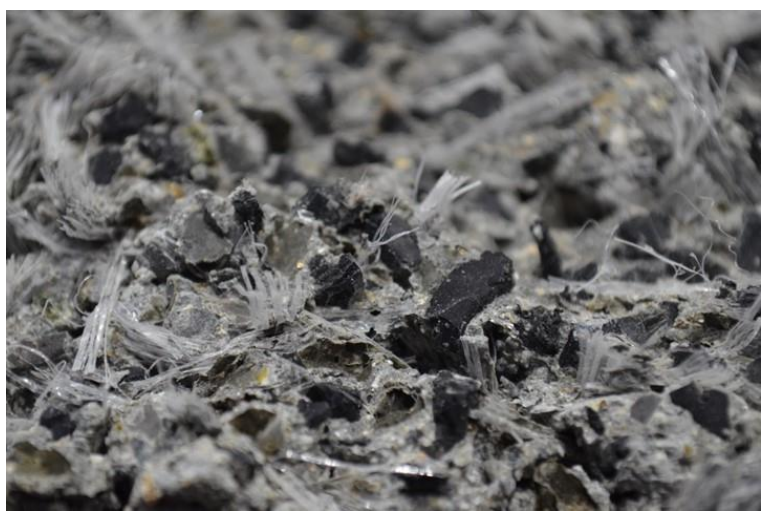

Fig. 14. Internal surface of failed mix-3 beam in flexure

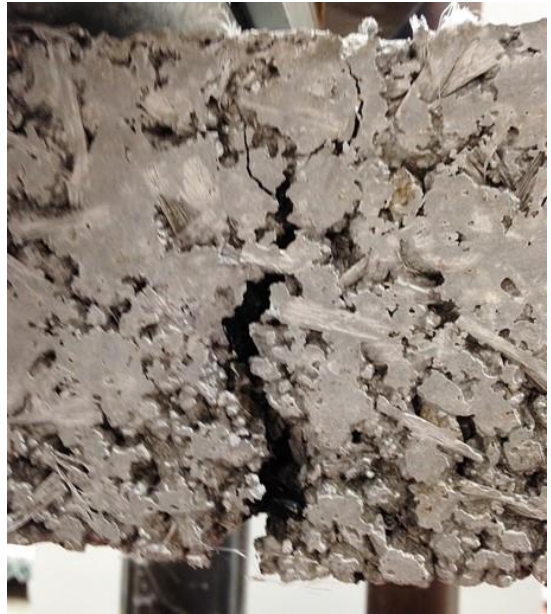

Fig. 15. Fibers bridging the crack in the mix -3 beam at failure

\section{Impact Testing}

Data analysis for impact testing required comparing the change in the height of the hanging mass for each test performed on each beam. Due to highly sensitive nature of the test, three beams were tested for each mix, and each beam was subjected to minimum three tests to obtain statistically consistent results. Figure 16 shows the average rise of the hanging mass for each mix as the indicator of energy not absorbed by the beam. As shown in this figure, the control specimens had the lowest energy absorbed during the impact. The application of tire-derived aggregate had a major impact on this value and caused the beam with mix-2 to absorb the most amount of energy. Adding fibers had reduced this amount for the mix-3.

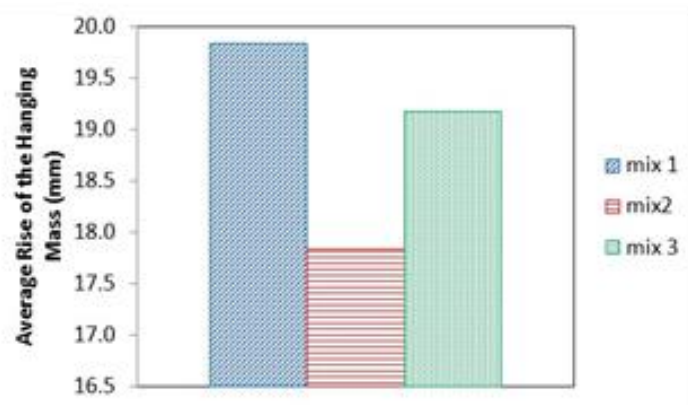

Fig. 16. Comparison of the transferred energy for each mix.

\section{CONCLUSION}

The obtained results for the mechanical properties of TDLWAC and LWAC samples were in agreement with existing literature. Flexural and compressive strength decreased with the addition of tire shreds. On the other hand, toughness and ductility increased with the addition of fibers. These effects were apparent from stress-strain or force-deformation curves as well as visual observations of the modes of failure and resulted failure surfaces. Moreover, the results of the non-destructive dynamic testing indicated that TDLWAC dissipates more impact energy than conventional lightweight aggregate concrete. However, application of fibers tends to increase the transferred energy. The comparison between the static and impact performance suggests that an optimum balance for a particular application is achievable by proportioning TDA and fibers within the cementitious matrix. 


\section{REFERENCES}

[1] F. M. Tehrani, and N. Miller, "Tire-derived aggregate cementitious materials: A Review of Mechanical Properties," in Cement-based Materials, Ed. by H. Saleh. Intech. 2018. DOI: 10.5772/intechopen.74313.

[2] A. Sadrinezhad, F. M. Tehrani, and B. Jeevanlal. "Shake table test of railway embankment consisting of LWA and TDA," Geo-Congress 2019: Earthquake Engineering and Soil Dynamics, Philadelphia, PA: $\begin{array}{llll}\text { ASCE, } & \text { pp. } & 31-39, & \end{array}$ https://ascelibrary.org/doi/10.1061/9780784482100.004

[3] F. M. Tehrani, A. Sadrinezhad, and M. Shafaei Bajestani. "Numerical simulation of the dynamic response of rail ballast with tire-derived aggregates," The $11^{\text {th }}$ US National Conference on Earthquake Engineering, Los Angeles, CA: Earthquake Engineering Research Institute (EERI), $\quad$ p. 1337. https://11ncee.org/images/program/papers/11NCEE-001337.pdf

[4] M. Nazari, F. M. Tehrani, M. Ansari, B. Jeevanlal, F. Rahman, and R. Farshidpour. "Green Strategies for Design and Construction of NonAuto Transportation Infrastructure," Report 19-17, San Jose, CA: Mineta Transportation Institute. 42 pp, 2019. https://transweb.sjsu.edu/sites/default/files/1872-Nazari-GreenStrategies-Design-Construction-Non-auto-TransportationInfrastructure.pdf

[5] F. M. Tehrani, "Notes on fiber-reinforced lightweight-aggregate structural concrete and concrete masonry," ESCSI E-Newsletter, September 2019. https://www.escsi.org/e-newsletter/notes-fiberreinforced-lightweight-aggregate-structural-concrete-concretemasonry/

[6] N. Miller. "Mechanical properties of rubberized lightweight aggregate concrete." Thesis, California State University, Fresno, CA. 2014.

[7] M. K. Batayneh, I. Marie, and I. Asi, "Promoting the use of crumb rubber Concrete in Developing Countries." Waste Management, vol. 28, no. 11, pp. 2171-2176. 2008. URL: http://www.ncbi.nlm.nih.gov/pubmed/18956487.

[8] C. A. Issa, and G. Salem, "Utilization of recycled crumb rubber as fine aggregates in concrete mix design." Construction and Building Materials, vol. 42, pp. 48-52. 2013. DOI: 10.1016/j.conbuildmat.2012.12.054.

[9] T. C. Ling, "Prediction of density and strength for rubberized concrete blocks." Construction and Building Materials, vol. 25, no. 11, pp. 4303-4306. 2011. DOI: 10.1016/j.conbuildmat.2011.04.074.

[10] N. M. Miller, and F. M. Tehrani, "Mechanical properties of rubberized lightweight aggregate concrete." Journal of Construction and Building Materials. Vol. 147, no. 30, pp. 264-271. 2017. [doi.org/10.1016/j.conbuildmat.2017.04.155]

[11] G. Wang, B. Zhang, Z. Shui, D. Tang, and Y. Kong, "Experimental study on the performance and microstructure of rubberized lightweight aggregate concrete." Progress in Rubber, Plastics and Recycling Technology, vol. 28, no. 4, pp. 147-156. 2012.

[12] F. M. Tehrani, J. Carreon, and N. Miller, "An investigation of tirederived lightweight aggregate concrete." in ACI Special Publication SP-334-5, Ed. by ACI Committee 555, no. 334, pp. 68-98. 2018.

[13] S. G. Shamasundar, M. Ghazinejad, F. M. Tehrani, and F. Khoshnoud, "3-D numerical modeling and analysis of mechanical properties of rubberized concrete," Thesis, California State University, Fresno, CA. 2017.

[14] I. B. Topcu, and N. Avcular. "Collision behaviors of rubberized concrete," Cement and Concrete Research, vol. 27, no. 12, pp. 1893 1898. 1997. DOI: 10.1016/S0008-8846(97)00204-4.

[15] J. Xue, and M. Shinozuka, "Rubberized concrete: a green structural material with enhanced energy-dissipation capability," Construction and Building Materials, vol. 42, pp. 196-204. 2013. DOI: 10.1016/j.conbuildmat.2013.01.005.
[16] L. Zheng, S. X. Huo, and Y. Yuan, "Experimental investigation on dynamic properties of rubberized concrete." Construction and Building Materials, vol. 22, no. 5, pp. 939-947. 2008. DOI 10.1016/j.conbuildmat.2007.03.005.

[17] F. M. Tehrani, and R. M. Serrano. "Crack propagation of concrete ties prestressed with single strand tendons." Journal of Civil Engineering Research, vol. 4, no. 3, pp. 71-81. 2014. DOI: $10.5923 /$ j.jce. 20140403.03

[18] A. Soto, and F. M. Tehrani. "Investigation of crack propagation in steel-concrete composite beams using fiber reinforcement." Periodica Polytechnica Civil Engineering. (10910). 2018. doi.org/10.3311/PPci.10910.

[19] S. Kakooei, M. A. Hazizan, M. Jamshidi, and J. Rouhi, "The effects of polypropylene fibers on the properties of reinforced concrete structures," Construction and Building Materials, vol. 27, no. 1, pp 73-77. 2012. DOI: 10.1016/j.conbuildmat.2011.08.015.

[20] Chris McComb, and Fariborz M. Tehrani. "Enhancement of shear transfer in composite deck with mechanical fasteners," Journal of Engineering Structures, vol. 88, no. 1, pp. 251-261. 2015. https://doi.org/10.1016/j.engstruct.2015.01.046

[21] S. Rico, R. Farshidpour, and F. M. Tehrani, "State-of-the-art report on fiber-reinforced lightweight-aggregate concrete masonry." Journal of Advances in Civil Engineering. (8078346). 2017. doi.org/10.1155/2017/8078346

[22] F. M. Tehrani, S. Rico, and R. Farshidpour. "Shear ductility of fiberreinforced lightweight-aggregate concrete masonry. The $11^{\text {th }}$ US National Conference on Earthquake Engineering, Los Angeles, CA: Earthquake Engineering Research Institute (EERI): pp. 1112, 2018 https://11ncee.org/images/program/papers/11NCEE-001112.pdf

[23] S. H. Chen, H. Y. Wang, J. W. Jhou, "Investigating the properties of lightweight concrete containing high contents of recycled green building materials," Construction and Building Materials, vol. 48, pp. 98-103. 2013. DOI: 10.1016/j.conbuildmat.2013.06.040.

[24] ASTM C39/C39M-16b, "Standard test method for compressive strength of cylindrical concrete specimens." ASTM International, West Conshohocken, PA, USA. 2016. DOI: 10.1520/C0039_C0039M-16B.

[25] Micro Measurements, "General purpose strain gages." Vishay Precision Group. Malvern, PA. 2016. www.vishayprecisiongroup.com/micro-measurements/stress-analysisstrain-gages.

[26] ASTM C78/C78M-16, "Standard test method for flexural strength of concrete (using single beam with third-point loading)." ASTM International, West Conshohocken, PA. 2016. DOI 10.1520/C0078_C0078M-16.

[27] A. M. Neville, "Properties of Concrete." New York, NY: Wiley. 1996.

Fariborz M. Tehrani, $\mathbf{P h D}$ is an associate professor in California State University, Fresno, with research interest in the area of sustainable and resilient structural engineering, mechanics, and materials (SR-SEMM). Dr. Tehrani is a voting member of ASTM C09.21 and ACI 213 Committees.

Nazmieh A. Masswadi, MSc is a civil engineering graduate of California State University, Fresno.

Nathan M. Miller, MSc is a civil engineering graduate of California State University, Fresno.

Arezoo Sadrinezhad, PhD is an assistant professor in California State University, Fresno, with research interest in the area of geotechnical engineering. 